\title{
A Spark of Humor in English Classrooms: Contribution and Consideration
}

"School without laughter is sheer torture."

Bell (2002)

\author{
Ani Pujiastuti \\ Islamic University of Indonesia
}

\begin{abstract}
This paper supports an idea that humor has a significant role in increasing the English learners' communicative competence. It is very common for teachers to present humor in English classrooms, whether it is purposely presented or spontaneously practiced in classroom activities. Yet, regardless of its significant contribution in language learning activities, it is highly likely that humor is one point that remains untouched in language learning. How many English textbooks containing humor in it? We hardly ever find any syllabi purposefully present the ability of students to tell or to understand jokes. Telling jokes in a serious classroom may be considered as something inappropriate as it may distract the classroom activities. Therefore, spontaneous humor may sometimes be viewed as an 'off task' behavior. However, it is sometimes forgotten that understanding other people's joke may be one of the keys of understanding other cultures, and more importantly, building a relationship with people from other countries.
\end{abstract}

Key words: humor, communicative competence, cultural values

\section{A. Background}

Studies have identified that the use of humor in classrooms can spark positive outcomes of learning as amusing activities can make students more relaxed, create a more comfortable classroom atmosphere, stimulate students' interest, and build a better relationship among their peers and teachers. Bell, (2005) asserted that humor can contribute to Second language Learning (SLL) activities both in and outside the classroom. Students and teacher can make use of 
humor to occasionally 'escape the classroom ordinaries'. Under the umbrella of Student Centered Learning (SCL) approach, playful interactions among learners can reduce the tension of learning, and narrow the gap among students from diverse levels and backgrounds: Outside the classrooms, students and teachers can engage in more casual interactions to increase their personal relationships. Additionally, according to Bell, language play has been investigated as having contribution in facilitating the development of language learning and has drawn the interest of many researchers in L1 (first language) for many years (2005).

In fact, as Tarone, cited in Bell (2005) put it, language play may help the learners in achieving sociolinguistics competence, since through this activity, learners may experience different voices. In the English classrooms, students may sometimes find it amusing to engage in funny classrooms experiences, such as imitating funny behaviors of their fellow students and especially, their teachers in criticizing someone. When their tension of learning is decreased, they can significantly increase their participation in the lesson. In this case, humorous may lead to two possible classroom situations; chance and chaos. Some questions need to be answered, however, especially related to how humorous activities are culturally viewed in foreign or second language learning.

\section{B. Humor and Culture}

Being able to actively communicate with others using the target language becomes one of the goals in language learning. For that purpose, understanding gramnatical rules alone.is not enough. Richards, et.al (1985) has clearly pointed out that communicative competency requires not only an ability to apply the grammatical rules in order to produce grammatically correct sentences, but ạlso to know when and where to use these sentences and to whom. Thus, for example, in communication, it is paramount for speakers to recognize the social setting, their relationship with others and the types of language that can be used in particular situation. When it comes to foreign or second language learning, the cultural values entrenched in both the native and target languages may create an interface among the speakers. Thus, it should be understandable that the definition of 'funny' may be different across cultures.

Different views used to perceive humor may lead to uncomfortable situations among speakers. There is sometimes a thin line between jokes and 
sarcasm. In the Indonesian society, it may sound funny to make jokes based on people's physical appearance or misfortune, such as saying that you can hardly recognize your friend in the darkness unless when he smiles, because his skin is too cark. We may consider this as funny, but imagine when this joke is told among-the African American society. Regardless of the difference existed across cultures, including in understanding jokes, Hayward (2004) reminded us of the importance to cultural awareness. It is unwise to say that one cultural value is correct and superior, while another one is wrong and inferior. In fact, they are just different.

In the same vein, Pepicello (1980) highlighted that the sophistication and unique roles of humor have been a source of attraction and become the object of study in western culture since the time of Aristotle. Accordingly, jokes may also serve a number of purposes in a culture. People use jokes as exercises in the use of language and the practice of social norms and cultural types. In other words, they provide a media for, and practice in, the familiar expressions that they all use in daily communication. In line with the above idea, as cited in Murcia (2001), Savignon asserted that understanding jokes which is included in discourse competence becomes one of the important components comprising communicative competence. In fact, the way people appreciate jokes will be different from one culture to another. When we laugh to something funny, it will be possible for other people from different cultural background to wonder why we can laugh to such a thing, and the other way around. It is apparent that the humor of people from one nation is a significant and unique part of the culture of that nation. For that reason, it is important to help our student appreciate jokes in -order to develop their understanding of other culture and language.

\section{Humor and Discourse Competence in Communication}

Canale and Swain (1980) and Canale (1983) argued that Communicative competence could be described as consisting of at least four components:

a) Linguistic Competence

Linguistic competence is the knowledge of lexical items and rules of morphology, syntax, sentence, grammar, semantics and phonology. These elements are necessary for constructing humor. 


\section{b) Sociolinguistics Competence}

This competence includes the socio cultural rules of using language in social contexts, such as how to give a gift using the appropriate cultural behaviors, knowing how to give and accept compliments based on the rules of the culture, and how, when, with whom and what kind of topic of jokes to be presented in particular.situation. Socio cultural rules are often connected to the functions of language (i.e., apologizing, requesting, asking pernission, and telling jokes).

\section{c) Discourse Competence}

This includes combination of grammatical forms and meanings for meaningful and appropriate contexts in both spoken and written language, for example, knowing when to laugh during a joke, knowing how and when to ask a question during a conversation, knowing how to organize ideas in an argumentative academic essay.

\section{d) Strategic Competence}

This competence comprises verbal and non verbal communication strategies for dealing with potential breakdown in communication, e.g. knowing how to explain directions by drawing a map; knowing how to ask someone to repeat what they said or show them you do not understand; being able to guess the meaning of words (in print or spoken) from the context, and what to do when we are failed in understanding jokes or make unsuccessful jokes.

Based on the components of communicative competence proposed by Canalc and Swain, we may be able to draw that humor may be viewed from those four above competences. The nature relationship of humor and communication is somewhat inseparable. In communicating with others in conversations, people have to know how to use appropriate language for appropriate context. Accordingly, the ability to understand other people's language in different context will also be crucial. In fact, when having a conversation in different languages, we need to position ourselves in our hearers' shoes. It means that we need to know how to use different expressions fordifferent situation. We also need to understand others expressions which are sometimes different from those in our native language, includes jokes. Knowing when to laugh and why we laugh in jokes told in the target language may show our ability in using and understanding those different expressions. 
We notice that in their daily activities, people may interact with others more in informal and casual occasions. Through those occasions, playful language or humor may be used in bigger portions. In relation with this point, Cook pointed out about the importance of language play for both adults and children's language learning. Just like the nature of children, Cook stated that, "adults spend great deal of their time in play and unreality through, for example, watching television, reading works of fiction, playing games, and using humor." Thus, since humor has a significant contribution in most of people's daily activities, then it is beneficial to include it in our language learning activities.

\section{Language Play and Language Learning}

There are several negative factors hindering our students' ability in learning a language, and one of them is anxiety (Krashen, 1988). Since almost everyone love to laugh, the use of humor can help the students to relax and help them to overcome their anxiety and stress so as to enable them to absorb the knowledge effectively. Humor can also cast away the students' worries and nervousness in making mistakes especially in their speaking abilities. We may notice our students play with some expressions such as "What's up?" and "What's down?" or "I love you too, I love you three, I love you four". This phenomena, according to Davies (2003) refers to the reality that English language learners with limited proficiency will tend to "exploit the linguistic and non-verbal resources at their disposal to create humor". It shows that we may need to pay attention to several points of views when relating humor to language proficiency. In relation to this, one point needs to be underlined here, that it is necessary for language teachers to match the type of humor they use based on different learners' language proficiency. Schmitz (2002) as cited in Bell (2002) pointed out that humor can be divided into three categories, which he bases on Graesser (1998) into: universal humor, culture based humor, and linguistics humor. According to him, the first type of humor will be suitable for the elementary level, intermediate learners may be benefited from universal humor plus some types of cultural-based jokes, while advanced students may appreciate the whole three types of humor.

However, as stated by Bell $(2002: 21)$, it is also worth to notice that humor may sometimes gives "a bad reputation as being frivolous and even unnecessary". Because of this, humor may cause more stress and discouragement for students, as 
they may be frustrated to not being able to understand something which is less serious or seems unimportant (compared to their struggle in understanding some grammatical patterns).

\section{E. Suggested Classroom's Activities}

Jokes are always related to context of the conversation. Since it may occur in various contexts, different humorous interactions will exist. Attardo (1994:320) divided the types of humors based on conversational context into joke telling in which the participants of the conversation either explicitly or implicitly announce that they will engage in a story telling session. Usually this type of humor is introduced in explicit markers such as, "Do you know the one..." or "You know what..." Another type of humor based on the context is conversational jokes which have strong contextual ties when occur in a conversation. The next type of humor is ritual joking which will be different across cultures. According to Attardo (1994), jokes are practiced in several "serious" ritual ceremonies in western culture, such as in marriage.

There are several ways to present humor in our classroom. Telling jokes will be able to develop our students' ability in listening and speaking. When they listen to each others' jokes, they will be able to decide when to laugh based on their ability in comprehending them. We can also assign the students to translate jokes from their cultures to English and to retell them; they can also take jokes from other nations from the websites and compare them with theirs. Besides, as almost everybody loves movie, comedy movies can be another aiternative to present jokes in our classroom. For writing activity, we can also create a wall joke magazine or jokes diary for our class. Sometimes, too, jokes can also be something serious. When we relate jokes to culture, we can discuss them with our students in terms of the stereotype of jokes from different cultures. For example, Indonesians tend to relate jokes with people's physical features, which is considered as rude in western culture.

We can use jokes and present humor to make our classroom colorful. Yet, there will be a time when this can hinder the process of teaching and learning, especially when we deal with younger students. They can think that we are not serious in teaching and this can blur our role as classroom manager. This can sometimes result in chaotic manner or uncontrollable behavior of our students. 
Indeed, we have to be able to make balance between when to put laughter in class and when to be serious and get the work done.

\section{F. Conclusions}

There is a close relationship between humor and communicative competence, as we need to acquire the four components in communicative competence, which are linguistics competence, sociolinguistics competence, discourse competence and strategic competence in order to be able to construct and understand humor in the target language. Since the nature of humor is amusing and relaxing, it may give considerable contribution in developing our students' communicative competence. However, teachers need to pay attention to the fact that understanding humor can sometimes be frustrating for students considering the nature of humor as something frivolous and less important. Besides, different cultural values students learn in the English classrooms may yield colorful perceptions to jokes. Thus, cultural awareness needs to be familiarized among students in order that they can understand and use jokes for different occasions and societies.

\section{Bibliography}

Attardo, S. (1994). Linguistic Theories of Humor. New York: Mouton de Gruyter.

Bell, N. (2002). Using and Understanding Humor in a Second Language: $A$ Case Study. Unpublished Doctoral Dissertation, University of Pennsylvania, Pennsylvania.

Bell N. (2005). Exploring L2 language play as an aid to SLL: A case study of . humor in NS-NNS interaction. Applied Linguistics, 26(2), 192-218.

Canale, M. (1983). From Communicative Competence to Communicative Language Pedagogy. In J. C. Richards \& R. Schmidt (Eds.), Language and Communication. London: Longman.

Canale, M., \& M. Swain. (1980). Theoretical basis of Communicative Approaches to Second Language Testing and teaching. Applied Linguistics, 1 (1): 1-47. 
Cook G: (2000). Language Play, Language Learning. Oxford: Oxford University Press.

Davies, C.E., (2003). How English-learners joke with native speakers: an interactional Sociolinguistics perspective on humor as collaborative discourse across cultures. Journal of Pragmatics, 35, 1361-1385.

Hayward, N. (2004). Insights into cultural divides. In Bruce, S. \& Rafoth, B. (Eds.) ESL Writers: A Guide for Writing Center Tutors (pp. 1-15). Portsmouth, NH: Heinemann Boynton/Cook Publishers.

- Holmes J. (2000). Politeness, power and provocation: How humor function in the workplace. Discourse studies, 2/2: 159-85.

Krashen, S. (1988). Second Language Acquisition and Second Language Learning. London: Prentice-Hall International.

Mish, C. F. (2004). The Merriam-Webster Dictionary. Massachusetts: MerriamWebster Inc.

Pepicello, W.J., (1987). Pragmatics of Humorous Language. International Journal of Second Language, pp.027-035.

Richards, J.C., John Platt \& Heidy Weber (1985). Longman Dictionary of Applied Linguistics. London: Longman

Savignon, S. J. (1972). Communicative Competence: An Experiment in Foreign Language Teaching. Philadelphia: Center for Curriculum Development

Taronc, E. (2000). Getting serious about language play, interlanguage variation and second language acquisition. In Swierzbin, B., F. Morris, M.E. Anderson, C. Klee, and E. Tarone (Eds), Social and Cognitive Factors in Second Language Acquisition: Selected Proceedings of the 1999 Second Language Research Forum. Somerville, MA: Cascadilla Press, 31-54. 